Available online http://iurnalmahasiswa.uma.ac.id/index.php/iiperta Diterima: Juli 2020; Disetujui: Agustus 2020; Dipublish: September 2020

\title{
Uji In-Vitro Ekstrak Kulit Jengkol (Pithecellobium jiringa) sebagai Biofungisida terhadap Fusarium oxysporum, Colletotrichum capsici, dan Cercospora capsici pada Tanaman Cabai \\ In-vitro inhibition activity of Jengkol Skin Ekstract as Protential biofungiside toward Fusarium oxysporum, Colletotrichum capsici, Cescespora Capsici on Chilli Pepper
}

\author{
Siswandi, Retna Astuti Kuswardani \& Maimunah* \\ Program Studi Agroteknologi, Fakultas Pertanian, Universitas Medan Area
}

\begin{abstract}
Abstrak
Penelitian bertujuan untuk mengetahui efektivitas ekstrak kulit jengkol (Pithecellobium jiringa) sebagai biofungisida terhadap penyakit layu Fusarium (Fusarium oxyospurum), Antraknosa (Colletotrichum capsici) dan daun bercak (Cercospora capsici) pada tanaman cabai merah (Capsicum annuum L), Penelitian ini menggunakan Rancangan Acak Lengkap non faktorial dengan tiga jenis replikasi. Faktor perlakuan konsentrasi ekstrak kulit jengkol yaitu kontrol negatif (tanpa pengobatan); kontrol positif (fungisida sintetis $0,2 \%$ ); dan konsentrasi berturutturut adalah 10\%; 20\%; 30\%; 40\%; 50\%; 60\%; 70\%; 80\%; 90\%; dan 100\%. Hasil penelitian menunjukkan bahwa pemberian ekstrak kulit jengkol efektif untuk mengendalikan jamur patogen (Colletotrichum capsici, Fusarium oxysporum dan Cercospora capsici) penyebab penyakit pada tanaman cabai merah. Ekstrak kulit batang jengkol pada konsentrasi 90\% didapatkan persentase penghambatan tertinggi Fusarum oxysporum sebesar 78,43 \% Sangat nyata dengan perlakuan ekstrak kulit batang jengkol 10\% dan kontrol negatif (tanpa perlakuan), pada konsentrasi ekstrak kulit jengkol 20\% diperoleh persentase penghambatan tertinggi Colletotrichum capsici 82,49\% Sangat nyata dengan perlakuan ekstrak kulit batang jengkol 10\%, kontrol negatif (tanpa perlakuan) dan pada konsentrasi ekstrak kulit jengkol 50\% diperoleh persentase inhibisi tertinggi Cercospora capsici sebesar 83,43\% Sangat signifikan dengan perlakuan ekstrak kulit batang jengkol 10\%, ekstrak kulit batang jengkol 20\%, ekstrak kulit batang jengkol 30\% dan hasil analisis. .
\end{abstract}

Kata Kunci: Ekstrak Kulit Jengkol, Fusarium oxysporum, Colletotrichum capsici, and Cercospora capsici.

\section{Abstract}

Research aims To determine the effectiveness of skin extract jengkol (Pithecellobium jiringa) effective as biofungisida against the disease-causing Fusarium wilt (Fusarium oxyospurum), Antraknosa (Colletotrichum capsici) and patches leaf (Cercospora capsici) on a red pepper plant (Capsicum annuum L) This research used non factorial completely randomized design with three replications. Factors treatment of skin extract concentration jengkol ie negative control (no treatment); positive control (synthetic fungicides 0.2\%); and successive concentration is 10\%; 20\%; 30\%; 40\%; 50\%; 60\%; 70\%; 80\%; 90\%; and 100\%. The results showed that administrationjengkol skin extract effective for controlling fungal pathogens (Colletotrichum capsici, Fusarium oxysporum and Cercospora capsici) that cause disease in plants red chili.Jengkol bark extract at a concentration of 90\% obtained the highest percentage inhibition Fusarum oxysporum as big as $78.43 \%$ Highly significant with bark extract treatment jengkol $10 \%$ and a negative control (no treatment), at a concentration of 20\% jengkol skin extract obtained the highest percentage inhibition of Colletotrichum capsici $82.49 \%$ Highly significant with bark extract treatment jengkol 10\%, negative control (no treatment) and at a concentration of 50\% jengkol skin extract obtained the highest percentage inhibition Cercospora capsici as big as 83.43\% Highly significant with bark extract treatment jengkol 10\%, 20\% jengkol bark extract, bark extract jengkol $30 \%$ and analytical results.

Keywords: skin Extract Jengkol, Fusarium oxysporum, Colletotrichum capsici, and Cercospora capsici.

How to Cite: Siswandi, Kuswardani, R.A. \& Maimunah. (2020). Uji In-Vitro Ekstrak Kulit Jengkol (Pithecellobium jiringa) sebagai Biofungisida terhadap Fusarium oxysporum, Colletotrichum capsici, dan Cercospora capsici pada Tanaman Cabai. Jurnal Ilmiah Pertanian (JIPERTA), 2 (2): 144-157

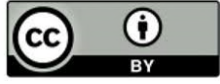




\section{PENDAHULUAN}

Indonesia salah satu negara tropis yang berada di garis khatulistiwa dengan sumber daya hayati \pm 30.000 spesies tumbuhan, dan baru \pm 7000 spesies di antaranya yang dikenal sebagai tumbuhan berkhasiat obat. Dengan kata lain masih banyak spesies tumbuhan di Indonesia yang belum dikenal manfaatnya diantaranya sebagai obat tradisional, pestisida nabati dan rempah masakan, sehingga berpeluang untuk dikaji lebih lanjut untuk tumbuhan yang lainnya.

Sejak tahun 1993 telah dikembangkan organik farming yang lebih ramah lingkungan, karena tidak menggunakan bahan-bahan kimia sintetis (Kardinan, 2001). Salah satu prospek yang bisa dikembangkan adalah pemanfaatan bahan organik, khususnya limbah organik yang masih memiliki senyawa aktif dan berpotensi sebagai obat. Salah satu limbah organik yang dapat digunakan dan bahan bakunya melipah serta mudah didapat yaitu kulit jengkol (Pithecellobium jiringa). Kulit Jengkol (Pithecellobium jiringa) selama ini tergolong limbah organik yang tidak termanfaatkan dan tidak memberikan nilai ekonomis. Sampah organik ini selain menganggu masyarakat dan parahnya memberi kontribusi pada banjir yang terjadi didaerah Medan (Hutasuhut, 2012). Sampah kulit jengkol selain menganggu lingkungan juga menganggu kenyamanan masyarakat dari bau yang tidak sedap. Di Pontianak mengeluarkan peraturan untuk menangkap masyarakat yang membuangkulit jengkol sembarangan. Lay (2009). Hal tersebut menunjukan bahwa perhatian akan kulit jengkol masih sangat kurang.

Hasil penelitian Rahayu, dkk (1998) diungkapkan bahwa kandungan senyawa kimia dalam kulit jengkol yaitu alkaloid, steroid/triterpenoid, saponin, dan tannin. Senyawa metabolik sekunder yang terkandung dalam kulit jengkol merupakan senyawa anti bakteri dan anti cendawan.

Senyawa flavonoid memiliki fungsi salah satunya digunakan sebagai anti mikroba dan anti virus (Parubak, A. S. 2013). Robinson (1995) juga menyatakan senyawa tanin yang terkandung dalam kulit jengkol sebagai antibakteri. Pernyataan (Osbourn et al 1996) keberadaan saponin dapat menjadi indikator ketahanan suatu jenis tumbuhan terhadap infeksi jamur, pernyataan ini diperkuat oleh pernyataan (Sugianitri, 2011) Saponin bersifat surfaktan yang berbentuk polar sehingga akan memecah lapisan lemak pada membran sel yang pada akhirnya menyebabkan gangguan permeabilitas membran sel, hal tersebut mengakibatkan proses difusi bahan atau zat-zat yang diperlukan oleh jamur dapat terganggu, akhirnya sel membengkak dan pecah. Selanjutnya (Hasibuan et al., 2020) menyampaikan bahwa flavonoid dari tanaman gamal mampu memiliki daya hambat sebesar $84 \%$ terhadap tiga jamur utama tanaman cabai ini.

Menurut Aminah dkk (2001), Tannin bekerja sebagai zat astringent, menysutkan jaringan dan menutup struktur protein pada kulit dan mukosa. Saponin bekerja menurunkan tegangan permukaan selaput mukosa straktus digestivus larva sehingga dinsing traktus digestivus menjadi korosif dan akhirnya rusak (Adetiya, 2017; Babara, et al., 2017; Eliyatiningsih, \& Mayasari, 2019). Provinsi Sumatera Utara menghasilkan produksi cabai merah dalam tiga tahun terakhir ini mengalami fluktuasi produksi yaitu 2012: 197.411 ton, 2013: 161.933 ton, 2014: 147.812 ton, (Badan Pusat Statistis Nasional, 2016). Jika dilihat dari data badan pusat statistik nasional pada tahun 2014 produksi cabai 
merah di Provinsi Sumatera Utara mengalami penurunan sebesar 14.123 ton atau 8,72\% dibandingkan tahun 2013. Salah satu penyebab turunnya fluktuasi produksi cabai merah diantaranya terkena penyakit layu fusarium, antraknosa, dan bercak daun Cercospora. Selain itu (Candra et al., 2019) menyatakan geminivirus mampu menyebabkan penurunan produksi hinggan $100 \%$.

Antraknosa merupakan salah satu penyakit yang menyerang tanaman cabai merah, penyakit ini disebabkan oleh cendawan Colletotrichum capsici. Menurut Efri tahun 2010, menyatakan kerugian yang disebabkan oleh penyakit Colletotrichum capsici mencapai $70 \%$, bahkan penyakit antraknosa dapat menurunkan produksi tananaman cabai hingga 100\% apabila didukung oleh kondisi yang basah, banyak hujan, dan lembab (Oka, dkk. 2001).

Selain itu penyakit layu fusarium merupakan salah satu penyakit yang juga menyerang tanaman cabai merah, penyakit ini disebabkan oleh cendawan Fusarium oxyosporum (Hutauruk, 2018; Ilyasa, et al., 2018; Sihotang, et al., 2019; Syahputra, et al, 2017). Adanya serangan cendawan ini menjadikan salah satu faktor pembatas yang menyebabkan terjadinya penurunan produksi cabai merah. Penyebaran cendawan Fusarium sangat cepat dan dapat menyebar ke tanaman lain dengan cara menginfeksi akar tanaman dengan menggunakan tabung kecambah atau miselium (Semangun, 2005). Menurut Phillips dkk, (2008), serangan penyakit layu fusarium yang disebabkan oleh cendawan Fusarium sp, menimbulkan kerugian produk tanaman hortikultura mencapai 40\% untuk wilayah Asia. Tingkat penyebaran cendawan Fusarium sangat cepat dan dapat menyebar ke tanaman lain dengan cara menginfeksi akar tanaman dengan menggunakan tabung kecambah atau miselium melalui air (Semangun, 2005). Selain beberapa jamur tersebut juga dapat diketahui bahwa di Indonesia kehilangan hasil produksi tanaman karena penyakit bercak daun Cercospora pada cabai berkisar antara 30 - $40 \%$. (Oka, dkk. 2001).

Sampai saat ini pengendalian penyakittersebut masih mengandalkan pestisida kimiawi. Tiga puluh persen pestisida terbuang ke tanah pada saat musim kemarau dan 80\% pada musim hujan terbuang ke perairan (Sibarani, 2008). Penggunaan pestisida kimiawi yang berlebihan memberikan dampak negatif terhadap lingkungan dan manusia, serta menganggu keseimbangan alam yang mengakibatkan hama menjadi resisten dan menjadi ancamana bagi predator, parasit, ikan, burung, maupun satwa liar tercemar bahan pestisida (Siswandi, dkk. 2016). Eksplorasi senyawa kimia yang berasal dari tumbuhan tingkat tinggi sebagai bahan pestisida nabati yang sifatnya ramah lingkungan penting untuk dilakukan penelitian.

\section{METODE PENELITIAN}

Bahan yang digunakan dalam penelitian ini antara lain : kulit jengkol, biakan Fusarium oxyosporum f.sp. capsici, biakan Colletotrichum capsici, biakan Cercospora Capsici, aquades, alkohol 70\%, spritus, plastik crabs, aluminium poil, tisuue, kapas, methanol, $\mathrm{HCl} 2 \mathrm{~N}$, serbuk logam $\mathrm{Mg}$, pereaksi Dragendorff, pereaksi LiebermannBurchard, pereaksi meyer, pereaksi molish, larutan (III) klorida, larutan asam klorida 
$2 \mathrm{~N}, \mathrm{n}$ - heksan, asam sulfat pekat, timbal (II) asetat, fungisida Benlox $50 \mathrm{WP}$ dan pereaksi $\mathrm{FeCl} 3$ 1\%.

Alat-alat yang digunakan dalam penelitian ini antara lain: Laminar air flow, gelas kimia, gelas ukur, pinset, mikroskop, kaca objek, cawan petri, kertas label, jarum ose, cork borer, bunsen, spatula, handsprayer, timbanganan alitik, mikropipet, labu erlyenmeyer, beaker glass, oven, incubator, hot plate stirrer, autoclave, vacuum rotary evaporator, ATK (alat tulis kantor), blender, pipet tetes, plat tetes, tabung reaksi, haemocytometer, botol tempat sampel dan kamera.

Penelitian dilakukan dengan metode eksperimental yaitu melakukan percobaan langsung dan dilakukan secara In vitro. Penelitian ini menggunakan Rancangan Acak Lengkap Non Faktorial. Faktor perlakuan konsentrasi ekstrak kulit jengkol dengan notasi (EJ) yang terdiri dari 12 taraf perlakuan sebagai berikut: EJ0 = Kontrol negatif (tanpa perlakuan 100\% PDA) EJ1 = Kontrol positif (fungisida sintetis 0,2\% + 100\% PDA) dan berturut-turut pada konsentrasi $10 \%, \quad 20 \%, 30 \%, 40 \%, 50 \%, 60 \%, 70 \%, 80 \%, 90 \%$ dan 100\%. Jumlah seluruh perlakuan: 12 Perlakuan Jumlah sampel biakan Fusarium oxysporum: 36 Cawan Petri Jumlah sampel biakan Colletotrichum capsici : 36 Cawan Petri Jumlah sampel biakan Cercospora capsici: 36 Cawan Petri Jumlah keseluruhan sampel : 108 Cawan Petri.

Pembuatan ekstrak dilakukan dengan menyediakan bahan sebanyak 3000 gr yang sudah di kering anginkan dan di haluskan, kemudian dimaserasi dengan pelarut methanol 15 L selama 3 x 24 jam. Larutan disaring kemudian diuapkan dengan menggunakan vacuum rotary evaporator (Buchii/R205) pada suhu (45-50)oC, kecepatan putaran (50 - 60) rpm, dan tekanan rendah $(150$ - 200) mm Hg, untuk mendapatkan larutan pekat ekstrak di tambahkan aquades dengan perbandingan 1: 1 setelah itu disimpan dalam lemari es $( \pm 40 \mathrm{C}$ ) untuk uji hayati.

Selanjutnya pembuatan media agar sebanyak $150 \mathrm{ml}$ diperoleh dengan cara sebagai berikut: Konsentrasi $0 \%$ (kontrol negatif) $=150 \mathrm{ml}$ aquades +10 gr PDA, konsentrasi $0 \%$ (kontrol positif) $=150 \mathrm{ml}$ aquades $+10 \mathrm{gr}$ PDA + fungisida sintetis Benlox $50 \mathrm{WP}$ 0,5 gr $(0,2 \%)$ Konsentrasi $10 \%=15 \mathrm{ml}$ ekstrak $+135 \mathrm{ml}$ aquades +10 gr PDA, konsentrasi $20 \%=30 \mathrm{ml}$ ekstrak $+120 \mathrm{ml}$ aquades $+10 \mathrm{gr}$ PDA, konsentrasi $30 \%=45 \mathrm{ml}$ ekstrak + $105 \mathrm{ml}$ aquades $+10 \mathrm{gr}$ PDA, konsentrasi $40 \%=60 \mathrm{ml}$ ekstrak $+90 \mathrm{ml}$ aquades $+10 \mathrm{gr}$ PDA, konsentrasi $50 \%=75 \mathrm{ml}$ ekstrak $+75 \mathrm{ml}$ aquades +10 gr PDA, konsentrasi $60 \%=$ $90 \mathrm{ml}$ ekstrak $+60 \mathrm{ml}$ aquades +10 gr PDA, konsentrasi $70 \%=105 \mathrm{ml}$ ekstrak $+45 \mathrm{ml}$ aquades +11 gr PDA, konsentrasi $80 \%=120 \mathrm{ml}$ ekstrak $+30 \mathrm{ml}$ aquades +12 gr PDA, konsentrasi $90 \%=135 \mathrm{ml}$ ekstrak $+15 \mathrm{ml}$ aquades +13 gr PDA, konsentrasi $100 \%=150$ $\mathrm{ml}$ ekstrak $+0 \mathrm{ml}$ aquades $+14 \mathrm{gr}$.

Isolasi patogen jamur Fusarium oxysporum, Colletotrichum capsici dan Cercospora capsici diperoleh dari tanaman cabai yang menunjukkan gejala layu fusarium, busuk kering pada buah dan bercak daun. Bagian tanaman yang menunjukkan gejala diambil bagian akar, buah dan daun dipotong dengan ukuran \pm panjang $0,5 \mathrm{~cm}$ dan direndam ke dalam alkhol $70 \%$ selama 1,5- 2 menit untuk mengurangi kontaminan organisme lain. Potongan sampel tersebut selanjutnya ditumbuhkan dimedia PDA dalam cawan petri dan 
Siswandi, Retna Astuti Kuswardani, \& Maimunah, Uji In-Vitro Ekstrak Kulit Jengkol (Pithecullum jiringa)

diinkubasi selama \pm 7 hari pada ruang bersuhu $26-28^{\circ} \mathrm{C}$. Setelah inkubasi selanjutnya dilakukan identifikasi secara mikrosopik bentuk konidia cendawan atau makrosepora.

Selanjutnya melakukan pengujian secara in vitro Uji daya hambat ekstrak kulit jengkol terhadap Fusarium oxysporum F, sp., Colletotrichum capsici, Cercospora capsici secara in vitro dilakukan di dalam cawan petri dengan menggunakan metode biakan cendawan (pada kontrol positif tidak ditambahkan ekstrak kulit jengkol sedangkan pada kontrol negatif yang dicampurkan ke media PDA adalah fungisida sintetik). Setelah itu pada bagian tengah media PDA yang telah beku diletakan potongan dari biakan Fusarium oxysporum F.

\section{HASIL DAN PEMBAHASAN \\ Uji Skrining Fitokimia}

Uji (skrining) fitokimia merupakan salah satu cara dalam upaya mengungkap potensi sumber daya metabolit skunder tumbuhan. Hasil analisis fitokimia dapat memberikan petunjuk tentang keberadaan komponen kimia (senyawa) jenis golongan steroid/triterpenoid, alkaloid, fenolik, biakan Colletotrichum capsici, biakan Cercospora capsici dengan cork borer diameter $1 \mathrm{~mm}$. Setelah inkubasi selama 2 x 24 jam/hari maka dilakukan pengamatan parameter flavonoid, saponin, dan tanin pada tumbuhan. Sebelum dilakukan skrining fitokimia dilakukan ekstraksi dan maserasi terhadap kulit jengkol. Ekstraksi dilakukan dengan pelarut metanol 96\% dan dimaserasi selama 3 x 24 jam. Didapatkan hasil ekstrak kulit jengkol dengan warna hijau pekat. Hasil skrining fitokimia kandungan kimia pada kulit jengkol terdapat pada Tabel 1.

Tabel 1. Hasil skrining fitokimia ekstrak metanol kulit jengkol (Pithecelobium jiringa)

\begin{tabular}{l|l|l|l}
\hline $\mathbf{N o}$ & Uji Fitokimia & Hasil & Kesimpulan \\
\hline $\mathbf{1}$ & Flavonoid & Terjadi warna merah, kuning, jingga pada lapisan amil alkohol & + \\
\hline $\mathbf{2}$ & Tanin & Terjadi warna biru atau hijau kehitaman & + \\
\hline $\mathbf{3}$ & Saponin & Buih tidak hilang setinggi 1-10 cm & + \\
\hline $\mathbf{4}$ & Alkaloida & $\mathbf{2}$ dari 3 pereaksi menghasilkan endapan yang sama & + \\
\hline 5 & $\begin{array}{l}\text { Steroid/ } \\
\text { Triterpenoid }\end{array}$ & $\begin{array}{l}\text { Terjadi warna ungu atau merah kemudian berubah menjadi } \\
\text { hijau biru }\end{array}$ & + \\
\hline
\end{tabular}

Keterangan: + (positif $)$ = ada; $-($ negatif $)=$ tidak ada

Berdasarkan hasil uji skrining fitokimia pada Tabel 1 dapat diketahui bahwa kulit jengkol mengandung senyawa kimia flavonoid, tannin, saponin, alkaloida, dan steroid/triterpenoid. Berdasarkan penelitian, ditemukan bahwa kandungan senyawa kimia yang terdapat didalam kulit jengkol (terpenoid, saponin, asam fenolat serta alkaloid), kulit jengkol kemudian memiliki potensi untuk digunakan sebagai biopestisida (Nurussakinah, 2010).

Senyawa-senyawa kimia pada tanaman tersebut diketahui memiliki beberapa senyawa yang berperan sebagai antimikroba seperti alkaloid, flavonoid, saponin, triterpenoid, dan komarin (Astuti et al., 2011; Djamil et al., 2012). Diantara senyawasenyawa tersebut diketahui memiliki mekanisme fisiologi tertentu, seperti anti jamur, anti bakteri, dan antivirus. Senyawa anti jamur mempunyai berbagai mekanisme penghambatan terhadap sel jamur. Djunaedy (2008) menyatakan bahwa senyawa anti jamur memiliki mekanisme kerja dengan cara menetralisasi enzim yang terkait dalam invasi dan kolonisasi jamur, merusak membran sel jamur, menghambat sistem enzim 
jamur sehingga mengganggu terbentuknya ujung hifa dan mempengaruhi sintesis asam nukleat dan protein.

Senyawa flavonoid merupakan golongan terbesar dari senyawa polifenol. Flavonoid bekerja dengan cara denaturasi protein sehingga meningkatkan permeabilitas membran sel. Denaturasi protein menyebabkan gangguan dalam pembentukan sel sehingga merubah komposisi komponen protein (Wahyuningtyas, 2008). Cowan (1999) dalam Firdaus (2015), menambahkan bahwa senyawa fenol yang terdapat pada flavonoid dapat mendenaturasi protein sel dan mengerutkan dinding sel sehingga menyebaban lisisnya dinding sel jamur. Selain itu, senyawa fenol melalui gugus hidroksi yang akan berikatan dengan gugus sulfihidril dari protein jamur sehingga mampu mengubah konformasi protein membran sel target yang mengakibatkan pertumbuhan sel jamur terganggu bahkan dapat mengalami kematian.

Saponin sebagai anti jamur, saponin merupakan senyawa larut air dan bersifat seperti foam (busa). Saponin tersebar luas pada tanaman tingkat tinggi dan telah dideteksi pada 70 keluarga tanaman (Daniel 2006). Saponin ditemukan sebagai antimikroba di alam. Saponin juga memiliki fungsi aktivitas biologi seperti antikanker, antiinflamasi dan antijamur (Kalaisezhiyen dan Sasikumar 2012; Senthilkumar dan Vijayakumari 2013). Wulansari (2009) juga menyatakan bahwa senyawa saponin mempunyai efek antibakteri dan anti jamur. Saponin sebagai anti jamur dengan mekanisme mengakibatkan sel mikroba lisis yaitu dengan mengganggu stabilitas membran selnya. Mekanisme saponin sebagai antifungi yaitu adanya pembentukan kompleks antara saponin dengan sterol pada membran plasma fungi, kemudian menghancurkan sel semipermeabel dan menyebabkan kematian pada sel fungi (Hoffmann 2003).

Tanin adalah senyawa polifenol yang bersifat asam dengan rasa sepat. Mekanisme tanin sebagai antijamur yaitu menghambat sintesis khitin yang digunakan untuk pembentukan dinding sel pada fungi dan merusak membran sel sehingga pembentukan fungi terhambat (Watson dan Preedy 2007). Sedangkan alkaloid adalah zat aktif dari tanaman yang berfungsi sebagai obat (Olivia, 2004). Secara umum tumbuhan yang mengandung senyawa alkaloid, secara fisik dapat diidentifikasi dengan ciri - ciri jelas, misalnya bergetah dan terasa pahit jika dicicipi (Mustanir, 2013). Menurut Aniszewki (2007) dalam Gholib (2009), alkaloid merupakan senyawa yang memiliki aktivitas antimikroba, yaitu menghambat esterase dan juga DNA dan RNA polimerase, juga menghambat respirasi sel dan berperan dalam interkalasi DNA. Mustikasari dan Ariyani (2010) menyatakan bahwa senyawa alkaloid memiliki aktivitas sebagai antimikroba dengan merusak dinding sel mikroba. Senyawa - senyawa golongan triterpenoid dan steroid diketahui memiliki aktifitas fisiologi tertentu, seperti antijamur, antibakteri, antivirus. Dimana aktivitas antimikroba dari terpenoid bekerja dengan mengganggu pertumbuhan dan perkembangan spora jamur akibat sifat toksik yang dimiliki senyawa triterpenoid (Ismaini 2011).

\section{Hasil Pengamatan Diameter Koloni Jamur Penyakit Pada Tanaman Cabai}

Dari daftar sidik ragam menunjukkan bahwa perlakuan pemberian ekstrak kulit jengkol (Pithecelobium jiringa) terhadap media pertumbuhan jamur pada 2-8 hari setelah inokulasi (HSI) berpengaruh sangat nyata terhadap penghambatan pertumbuhan diameter koloni jamur Fusarium oxysporum. Rataan pertumbuhan diameter koloni jamur Fusarium oxysporum dengan perlakuan pemberian ekstrak kulit jengkol (Pithecelobium jiringa) terhadap media pertumbuhan jamur pada 2-8 hari setelah inokulasi (HSI) selama pengamatan dan notasinya dapat dilihat pada Tabel 2 . 
Siswandi, Retna Astuti Kuswardani, \& Maimunah, Uji In-Vitro Ekstrak Kulit Jengkol (Pithecullum jiringa)

Tabel 2. Data Diameter (cm) Koloni Jamur Fusarium oxysporum pada 2-8 hari setelah inokulasi (HSI) Dengan pemberian Ekstrak Kulit Jengkol (Pithecelobium jiringa)

\begin{tabular}{|c|c|c|c|c|c|c|c|c|c|c|c|c|c|c|}
\hline \multirow{3}{*}{ Perlakuan } & \multicolumn{14}{|c|}{ Diameter Koloni Jamur Fusarium Oxsporum } \\
\hline & \multirow{2}{*}{\multicolumn{2}{|c|}{$\begin{array}{l}2 \\
\text { His }\end{array}$}} & \multirow{2}{*}{\multicolumn{2}{|c|}{$\begin{array}{l}3 \\
\text { His }\end{array}$}} & \multirow{2}{*}{\multicolumn{2}{|c|}{$\begin{array}{l}4 \\
\text { Hsi } \\
\end{array}$}} & \multirow{2}{*}{\multicolumn{2}{|c|}{$\begin{array}{l}5 \\
\text { Hsi }\end{array}$}} & \multirow{2}{*}{\multicolumn{2}{|c|}{$\begin{array}{l}6 \\
\text { Hsi }\end{array}$}} & \multirow{2}{*}{\multicolumn{2}{|c|}{$\begin{array}{l}7 \\
\text { Hsi }\end{array}$}} & \multirow{2}{*}{\multicolumn{2}{|c|}{8 His }} \\
\hline & & & & & & & & & & & & & & \\
\hline $\mathrm{EJ}_{0}$ & 1.73 & a & 2.25 & a & 3.15 & a & 4.06 & $\mathrm{a}$ & 4.90 & $\mathrm{a}$ & 5.80 & a & 6.81 & $\mathrm{a}$ \\
\hline $\mathrm{EJ}]_{1}$ & 1.00 & c & 1.00 & c & 1.00 & $\mathrm{~d}$ & 1.00 & $d$ & 1.00 & $\mathrm{~d}$ & 1.10 & $\mathrm{~d}$ & 1.10 & $\mathrm{~d}$ \\
\hline $\mathrm{EJ} 2$ & 1.24 & $b$ & 1.65 & b & 1.97 & b & 2.26 & b & 2.70 & b & 3.33 & b & 4.11 & b \\
\hline $\mathrm{EJ}_{3}$ & 1.00 & $\mathrm{c}$ & 1.18 & c & 1.31 & c & 1.55 & c & 1.73 & c & 1.83 & $c$ & 1.83 & $c$ \\
\hline $\mathrm{EJ}_{4}$ & 1.00 & c & 1.08 & c & 1.33 & c & 1.60 & c & 1.71 & c & 1.71 & $c$ & 1.71 & $c$ \\
\hline $\mathrm{EJ}_{5}$ & 1.00 & $\mathrm{c}$ & 1.08 & c & 1.31 & $c$ & 1.55 & $c$ & 1.67 & $c$ & 1.67 & $c$ & 1.67 & $c$ \\
\hline $\mathrm{EJ}_{6}$ & 1.00 & c & 1.05 & $c$ & 1.34 & c & 1.63 & C & 1.72 & $c$ & 1.72 & $\mathrm{c}$ & 1.72 & $c$ \\
\hline $\mathrm{E}]_{7}$ & 1.00 & C & 1.05 & c & 1.28 & c & 1.56 & c & 1.57 & $\mathrm{c}$ & 1.57 & $\mathrm{~cd}$ & 1.57 & $\mathrm{c}$ \\
\hline $\mathrm{EJ} 8$ & 1.00 & c & 1.03 & c & 1.31 & c & 1.60 & c & 1.72 & c & 1.73 & $\mathrm{c}$ & 1.73 & $c$ \\
\hline EJ9 & 1.00 & $\mathrm{c}$ & 1.03 & C & 1.31 & c & 1.58 & c & 1.63 & c & 1.63 & $c$ & 1.63 & $c$ \\
\hline EJ10 & 1.00 & c & 1.03 & $c$ & 1.21 & $\mathrm{~cd}$ & 1.40 & c & 1.46 & $c$ & 1.46 & $\mathrm{~cd}$ & 1.46 & $\mathrm{~cd}$ \\
\hline $\mathrm{EJ} 11$ & 1.00 & $\mathrm{C}$ & 1.03 & $\mathrm{C}$ & 1.25 & C & 1.48 & $\mathrm{C}$ & 1.51 & $\mathrm{C}$ & 1.51 & $\mathrm{~cd}$ & 1.51 & $\mathrm{~cd}$ \\
\hline
\end{tabular}

Keterangan : Angka yang diikuti huruf yang sama pada kolom yang sama berbeda tidak nyata pada taraf $\alpha=0,01$

Dengan perlakuan pemberian ekstrak kulit jengkol pada media pertumbuhan jamur memberikan pengaruh sangat nyata pada 2-8 hari setelah inokulasi. Hasil pengamatan perlakuan EJ10 sudah memberikan hasil yang dapat menghambat pertumbuhan koloni jamur (Fusarium oxysporum) di cawan petri, perlakuan ekstrak kulit jengkol (90\%) menunjukan berbeda sangat nyata dengan EJ2 ekstrak kulit jengkol (10\%), dan berbeda sangat nyata dengan perlakuan EJ0 kontrol negatif (-) tanpa perlakuan, tetapi tidak berbeda nyata dengan perlakuan EJ1 (+) fungisida sintetis Benlox 50 WP 0,2\% dan tidak berbeda nyata dengan beberapa perlakuan EJ4 sampai EJ9, dan perlakuan EJ11 ekstrak kulit jengkol (100\%) tidak berbeda nyata dengan perlakuan EJ1 dan EJ10. Perlakuan EJ10 ekstrak kulit jengkol (90\%), merupakan perlakuan yang dapat menghambat pertumbuhan diameter koloni. Akan tetapi pada perlakuan EJ3 ekstrak kulit jengkol (20\%) sudah mampu menghambat pertumbuhan koloni jamur tetapi tingkat penghambatan yang lebih baik berada pada perlakuan EJ10. Dimana perlakuan EJ10 ekstrak kulit jengkol (90\%), setara dengan perlakuan EJ1 kontrol positif (+) fungisida sintetis Benlox 50 WP 0,2\%, hal ini juga terjadi pada jenis jamur yang dilakukan pada penelitian ini yaitu Colletotrichum capsici.

\section{Hasil Pengamatan Diameter Koloni Jamur Penyakit pada Tanaman Cabai Colletotrichum capsici}

Dari daftar sidik ragam menunjukkan bahwa perlakuan pemberian ekstrak kulit jengkol (Pithecelobium jiringa) terhadap media pertumbuhan jamur berpengaruh sangat nyata terhadap penghambatan pertumbuhan diameter koloni jamur Colletotrichum capsici. Rataan pertumbuhan diameter koloni jamur Colletotrichum capsici dengan perlakuan pemberian ekstrak kulit jengkol (Pithecelobium jiringa) terhadap media pertumbuhan jamur pada 2-8 hari setelah inokulasi (HSI) selama pengamatan dan notasinya dapat dilihat pada Tabel 3. 
Tabel .3. Data Diameter (cm) Koloni Jamur Colletrotichum capsici pada 2-8 hari setelah inokulasi (HSI) Dengan Perlakuan Ekstrak Kulit Jengkol (Pithecelobium jiringa)

\begin{tabular}{|c|c|c|c|c|c|c|c|c|c|c|c|c|c|c|}
\hline \multirow[b]{2}{*}{ Perlakuan } & \multicolumn{14}{|c|}{ Diameter Koloni Jamur Colletrotichum Capsici } \\
\hline & $\begin{array}{c}2 \\
\mathrm{Hsi}\end{array}$ & & $\begin{array}{c}3 \\
\mathrm{Hsi}\end{array}$ & & $\begin{array}{c}4 \\
\text { Hsi }\end{array}$ & & $\begin{array}{c}5 \\
\text { Hsi }\end{array}$ & & $\begin{array}{c}6 \\
\mathrm{His}\end{array}$ & & $\begin{array}{c}7 \\
\text { His }\end{array}$ & & & \\
\hline $\mathrm{EJ} 0$ & 1.48 & $a$ & 2.53 & $a$ & 3.31 & $a$ & 3.53 & $a$ & 4.16 & $a$ & 5.11 & $a$ & 5.71 & $\mathrm{a}$ \\
\hline EJ ${ }_{1}$ & 1.00 & b & 1.00 & c & 1.00 & c & 1.00 & $\mathrm{c}$ & 1.00 & c & 1.00 & c & 1.00 & c \\
\hline $\mathrm{EJ}_{2}$ & 1.00 & b & 1.13 & b & 1.93 & b & 2.26 & b & 2.61 & b & 3.01 & b & 3.71 & b \\
\hline $\mathrm{EJ}_{3}$ & 1.00 & b & 1.00 & $\mathrm{c}$ & 1.00 & $b$ & 1.00 & $\mathrm{c}$ & 1.00 & $\mathrm{c}$ & 1.00 & $\mathrm{c}$ & 1.00 & c \\
\hline $\mathrm{EJ}_{4}$ & 1.00 & b & 1.00 & c & 1.00 & $\mathrm{~b}$ & 1.00 & c & 1.00 & c & 1.00 & c & 1.00 & c \\
\hline $\mathrm{EJ}_{5}$ & 1.00 & b & 1.00 & c & 1.00 & b & 1.00 & c & 1.00 & c & 1.00 & $\mathrm{c}$ & 1.00 & c \\
\hline EJ 6 & 1.00 & b & 1.00 & c & 1.00 & b & 1.00 & C & 1.00 & c & 1.00 & c & 1.00 & c \\
\hline EJ7 & 1.00 & b & 1.00 & c & 1.00 & b & 1.00 & c & 1.00 & c & 1.00 & $\mathrm{c}$ & 1.00 & c \\
\hline $\mathrm{EJ} 8$ & 1.00 & b & 1.00 & c & 1.00 & b & 1.00 & C & 1.00 & c & 1.00 & $c$ & 1.00 & c \\
\hline EJ9 & 1.00 & b & 1.00 & c & 1.00 & b & 1.00 & c & 1.00 & c & 1.00 & c & 1.00 & c \\
\hline$E J_{10}$ & 1.00 & b & 1.00 & $\mathrm{c}$ & 1.00 & b & 1.00 & $\mathrm{c}$ & 1.00 & c & 1.00 & $\mathrm{c}$ & 1.00 & c \\
\hline$E J_{11}$ & 1.00 & b & 1.00 & c & 1.00 & b & 1.00 & c & 1.00 & C & 1.00 & c & 1.00 & c \\
\hline
\end{tabular}

Keterangan : Angka yang diikuti huruf yang sama pada kolom yang sama berbeda tidak nyata pada taraf $\alpha=0,01$

Dengan perlakuan pemberian ekstrak kulit jengkol pada media pertumbuhan jamur memberikan pengaruh sangat nyata, hasil pengamatan menunjukkan perlakuan EJ3 = ekstrak kulit jengkol (20\%) sudah memberikan hasil yang dapat menghambat pertumbuhan koloni jamur (Colletotrichum capsici) di cawan petri, perlakuan EJ0 = kontrol negatif (-) tanpa perlakuan ini berbeda sangat nyata dengan perlakuan EJ2 = ekstrak kulit jengkol 10\%). Perlakuan ekstrak kulit dari daftar sidik ragam menunjukkan bahwa perlakuan pemberian ekstrak kulit jengkol (Pithecelobium jiringa) pada media pertumbuhan jamur pada 2-8 hari setelah inokulasi (HSI) berpengaruh sangat

nyata terhadap jengkol EJ3 tidak berbeda nyata dengan perlakuan EJ1 = kontrol (+) positif fungisida sintetis Benlox 50 WP 0,2\%, dan juga tidak berbeda nyata dengan perlakuan EJ4 dan EJ11. Hal ini menunjukan perlakuan EJ3 = $(20 \%)$ merupakan perlakuan ekstrak yang cukup baik dengan menghambat pertumbuhan diameter koloni yang tidak bertambah yaitu $1,00 \mathrm{~cm}$.

\section{Hasil Pengamatan Diameter Koloni Jamur Penyakit Pada Tanaman Cabai Cercospoa capsici}

Penghambatan pertumbuhan diameter koloni jamur Cercospora capsici. Rataan pertumbuhan diameter koloni jamur Fusarium oxysporum dengan perlakuan pemberian ekstrak kulit jengkol (Pithecelobium jiringa) terhadap media pertumbuhan jamur pada 28 hari setelah inokulasi (HSI) selama pengamatan dan notasinya dapat dilihat pada Tabel 4. 
Siswandi, Retna Astuti Kuswardani, \& Maimunah, Uji In-Vitro Ekstrak Kulit Jengkol (Pithecullum jiringa)

Tabel 4. Data Diameter (cm) Koloni Jamur Cercospora capsici pada 2-8 hari setelah inokulasi (HSI) Dengan Perlakuan Ekstrak Kulit Jengkol (Pithecelobium jiringa)

\begin{tabular}{|c|c|c|c|c|c|c|c|c|c|c|c|c|c|c|}
\hline \multirow[b]{2}{*}{ Perlakuan } & \multicolumn{14}{|c|}{ Diameter Koloni Jamur Cercospora capsici } \\
\hline & $\begin{array}{c}2 \\
\text { Hsi }\end{array}$ & & $\begin{array}{c}3 \\
\text { His }\end{array}$ & & $\begin{array}{c}4 \\
\text { Hsi }\end{array}$ & & $\begin{array}{c}5 \\
\text { Hsi }\end{array}$ & & $\begin{array}{c}6 \\
\text { Hsi }\end{array}$ & & $\begin{array}{l}7 \\
\text { Hsi }\end{array}$ & & $\begin{array}{r}8 \\
\mathrm{H}\end{array}$ & \\
\hline$E J_{0}$ & 1.91 & $\mathrm{a}$ & 2.31 & $\mathrm{a}$ & 3.18 & $\mathrm{a}$ & 3.81 & $\mathrm{a}$ & 4.81 & $\mathrm{a}$ & 5.81 & $\mathrm{a}$ & 6.98 & $\mathrm{a}$ \\
\hline $\mathrm{EJ}_{1}$ & 1.00 & b & 1.00 & $\mathrm{c}$ & 1.00 & $\mathrm{c}$ & 1.00 & $\mathrm{~d}$ & 1.00 & $\mathrm{e}$ & 1.05 & $\mathrm{~d}$ & 1.05 & $\mathrm{e}$ \\
\hline$E J_{2}$ & 1.00 & b & 1.53 & b & 1.75 & b & 2.06 & b & 2.34 & b & 2.63 & b & 3.11 & b \\
\hline $\mathrm{EJ}_{3}$ & 1.00 & $\mathrm{~b}$ & 1.00 & c & 1.06 & C & 1.26 & c & 1.48 & c & 1.70 & c & 2.26 & c \\
\hline $\mathrm{EJ}_{4}$ & 1.00 & $\mathrm{~b}$ & 1.00 & c & 1.13 & c & 1.21 & $\mathrm{~cd}$ & 1.50 & c & 1.78 & C & 1.95 & c \\
\hline $\mathrm{EJ} 5$ & 1.00 & $\mathrm{~b}$ & 1.00 & c & 1.03 & c & 1.23 & $\mathrm{~cd}$ & 1.23 & d & 1.23 & $d$ & 1.50 & $\mathrm{~d}$ \\
\hline $\mathrm{EJ}_{6}$ & 1.00 & $\mathrm{~b}$ & 1.00 & c & 1.01 & c & 1.08 & $\mathrm{~cd}$ & 1.05 & de & 1.05 & d & 1.15 & de \\
\hline $\mathrm{EJ}_{7}$ & 1.00 & $\mathrm{~b}$ & 1.00 & c & 1.00 & c & 1.05 & $\mathrm{~cd}$ & 1.05 & de & 1.05 & $d$ & 1.13 & de \\
\hline $\mathrm{EJ}_{8}$ & 1.00 & $\mathrm{~b}$ & 1.00 & c & 1.00 & c & 1.05 & $\mathrm{~cd}$ & 1.05 & de & 1.05 & $d$ & 1.13 & de \\
\hline EJ9 & 1.00 & $\mathrm{~b}$ & 1.00 & c & 1.00 & C & 1.05 & $\mathrm{~cd}$ & 1.05 & de & 1.05 & d & 1.11 & de \\
\hline $\mathrm{EJ}_{10}$ & 1.00 & $\mathrm{~b}$ & 1.00 & c & 1.00 & c & 1.05 & & 1.05 & de & 1.05 & d & 1.10 & $\mathrm{e}$ \\
\hline EJ11 & 1.00 & $\mathrm{~b}$ & 1.00 & $\mathrm{c}$ & 1.00 & $\mathrm{c}$ & 1.05 & $\mathrm{~cd}$ & 1.05 & de & 1.05 & d & 1.10 & $\mathrm{e}$ \\
\hline
\end{tabular}

Keterangan : Angka yang diikuti huruf yang sama pada kolom yang sama berbeda tidak nyata pada taraf $\alpha=0,01$

Dengan perlakuan pemberian ekstrak kulit jengkol pada media pertumbuhan jamur memberikan pengaruh sangat nyata pada 2-8 hari setelah inokulasi, hasil pengamatan menunjukkan perlakuan EJ6 sudah memberikan hasil yang dapat menghambat pertumbuhan koloni jamur (Cercospora capsici) di cawan petri, perlakuan ekstrak kulit jengkol (50\%), menunjukan berbeda sangat nyata dengan EJ2 ekstrak kulit jengkol (10\%) dan EJ0 kontrol negatif (-) tanpa perlakuan, akan tetapi pada perlakuan EJ5 tidak berbeda nyata dengan perlakuan EJ1 kontrol positif (+) fungisida sintetis Benlox 50 WP 0,2\% dan perlakuan EJ10 sampai dengan EJ11, Akan tetapi perlakuan EJ6 berbeda nyata dengan perlakuan EJ3 sampai EJ4 ekstrak kulit jengkol (30\%).

Perlakuan EJ6 ekstrak kulit jengkol merupakan perlakuan terbaik dengan menghambat pertumbuhan diameter koloni setara dengan perlakuan EJ1 kontrol positif (+) fungisida sintetis Benlox 50 WP 0,2\%. Hasil pengamatan diameter pertumbuhan dari ketiga jamur dengan pemberian ekstrak kulit jengkol pada media pertumbuhan jamur memperlihatkanpengaruh konsentrasi yang berbeda, hal ini dikarenakan kemampuan pertumbuhan jamur dan fisologis dari masing-masing jamur berbeda dalam mekanisme pertumbuhan.

Pada pengamatan diameter pertumbuhan jamur Colletotrichum capsici, Fusariumoxysporum dan Cercosporacapsici dengan perlakuan pemberian ekstrak kulit jengkol pada media pertumbuhan jamur memberikan pengaruh yang berbeda, dimana pengaruh pemberian ekstrak kulit jengkol pada media pertumbuhan jamur pada EJ3 konsentrasi 20\% sudah mampu menghambat pertumbuhan jamur Colletotrichum capsici, tetapi tidak mampu menghambat pertumbuhan jamur Fusarium oxysporum dan Cercospora capsici.

Pemberian ekstrak kulit jengkol pada media pertumbuhan jamur pada EJ10 konsentrasi 90\% sudah mampu menghambat pertumbuhan jamur Fusarium oxysporum tetapi tidak mampu menghambat pertumbuhan Colletotrichum capsici, Fusarium oxysporum dan Cercospora capsici. Perlakuan EJ3 ekstrak kulit jengkol (Pithecelobium jiringa) (20\%) pada jamur Colletotrichum capsici dan perlakuan 
EJ10 ekstrak kulit jengkol (90\%) pada jamur Fusarium oxysporum dan Cercospora capsici adalah perlakuan terbaik EJ6 dengan konsentrasi (50\%) sudah setara dengan perlakuan EJ0 kontrol positif (+) fungisida sintetis Benlox 50 WP 0,2\% yang sudah dapat terhambat.

\section{Persentase Penghambatan Ketiga Jamur Patogen}

Dari daftar sidik ragam menunjukkan bahwa perlakuan pemberian ekstrak kulit jengkol terhadap media pertumbuhan jamur berpengaruh sangat nyata terhadap persentasepenghambatan pertumbuhan jamur Colletotrichum capsici, Fusarium oxysporum dan jamur Cercospora capsici. Pemberian ekstrak kulit jengkol Fusarium oxysporum pada media pertumbuhan jamur pada EJ6 konsentrasi 50\% mampu menghambat pertumbuhan dari jamur tersebut yaitu, pertumbuhan dari, Colletotrichum capsici, Fusarium oxysporum dan Cercospora capsici.

Penghambatan pertumbuhan diameter koloni dari ketiga jamur yaitu, Colletotrichum capsici, Fusarium oxysporum dan Cercospora capsici diakibatkan adanya kandungan senyawa metabolit sekunder yang dimiliki oleh kulit jengkol yang bersifat antifungi. Senyawa antifungi mempunyai berbagai mekanisme penghambatan terhadap sel jamur Cercospora capsici.

Rataan persentase penghambatan pertumbuhan ketiga jamur tersebut dengan perlakuan pemberian ekstrak kulit jengkol terhadap media pertumbuhan jamur pada 8 hari setelah inokulasi (HSI) selama pengamatan dan notasinya dapat dilihat pada Tabel 5.

Tabel 5. Data Persentase (\%) Penghambatan Jamur Colletotrichum capsici, Fusarium oxysporum dan Cercospora capsici Perlakuan Pemberian Pemberian Ekstrak Kulit Jengkol (Pithecelobium jiringa)

\begin{tabular}{|c|c|c|c|c|c|c|}
\hline \multirow{3}{*}{$\begin{array}{c}\text { Perlakuan } \\
\text { E }]_{0}\end{array}$} & \multicolumn{6}{|c|}{ Persentase Penghambatan Jamur Patogen } \\
\hline & \multicolumn{2}{|c|}{$\begin{array}{c}\text { Colletotrichum } \\
\text { capici }\end{array}$} & \multicolumn{2}{|c|}{$\begin{array}{c}\text { Fusarium } \\
\text { oxyosporum }\end{array}$} & \multicolumn{2}{|c|}{ Cercospora capsici } \\
\hline & 0 & $\mathrm{c}$ & 0 & $\mathrm{~d}$ & 0 & $\mathrm{f}$ \\
\hline EJ 1 & 82.49 & a & 83.47 & a & 84.88 & $\mathrm{a}$ \\
\hline $\mathrm{E} \mathrm{J}_{2}$ & 34.93 & b & 39.6 & $\mathrm{c}$ & 55.24 & $\mathrm{e}$ \\
\hline $\mathrm{E}]_{3}$ & 82.49 & $\mathrm{a}$ & 72.79 & b & 67.59 & $\mathrm{~d}$ \\
\hline $\mathrm{E}]_{4}$ & 82.49 & $\mathrm{a}$ & 74.65 & $\mathrm{~b}$ & 72.31 & $\mathrm{c}$ \\
\hline $\mathrm{E} \mathrm{J}_{5}$ & 82.49 & $\mathrm{a}$ & 75.27 & b & 78.09 & b \\
\hline $\mathrm{E}]_{6}$ & 82.49 & $\mathrm{a}$ & 74.59 & b & 83.43 & $\mathrm{a}$ \\
\hline $\mathrm{EJ} 7$ & 82.49 & $\mathrm{a}$ & 76.62 & b & 83.65 & $\mathrm{a}$ \\
\hline EJ8 & 82.49 & $\mathrm{a}$ & 74.44 & b & 83.92 & $\mathrm{a}$ \\
\hline EJ9 & 82.49 & $\mathrm{a}$ & 76 & $\mathrm{~b}$ & 83.92 & $\mathrm{a}$ \\
\hline$E J_{10}$ & 82.49 & $\mathrm{a}$ & 78.43 & $a b$ & 84.15 & $\mathrm{a}$ \\
\hline EJ11 & 82.49 & $\mathrm{a}$ & 77.67 & $a b$ & 84.15 & $\mathrm{a}$ \\
\hline
\end{tabular}

Keterangan : Angka yang diikuti huruf yang sama pada kolom yang sama berbeda tidak nyata pada taraf $\alpha=0,01$

Pada parameter pengamatan rata-rata persentase penghambatan pertumbuhan jamur patogen Colletotrichum capsici, Fusarium oxysporum dan Colletotrichum capsici dengan perlakuan pemberian ekstrak kulit jengkol terhadap media pertumbuhan jamur memberikan pengaruh sangat nyata. Pada pengamatan rata-rata persentase penghambatan pertumbuhan jamur patogen Colletotrichum capsici, perlakuan EJ3 ekstrak kulit jengkol (20\%) sudah memberikan hasil yang dapat menghambat pertumbuhan koloni jamur (Colletotrichum capsici) di cawan petri, perlakuan adalah EJ3 ekstrak kulit jengkol (20\%) menunjukan berbeda sangat nyata dengan, EJ2 ekstrak kulit jengkol (10\%) dan EJ0 kontrol negatif (-) tanpa perlakuan tetapi tidak berbeda nyata dengan perlakuan EJ1 kontrol positif (+) fungisida sintetis Benlox 50 WP 0,2\% dan perlakuan ekstrak EJ4 sampai 
dengan EJ11. Pada pengamatan rata-rata persentase penghambatan pertumbuhan jamur patogen Fusarium oxysporum menunjukkan perlakuan EJ10 sudah memberikan hasil yang dapat menghambat pertumbuhan koloni jamur (Colletotrichum capsici) di cawan petri, perlakuan ekstrak kulit jengkol (90\%), menunjukan berbeda sangat nyata dengan EJ2 ekstrak kulit jengkol (10\%), akan tetapi pada perlakuan EJ3 sampai EJ9 pemberian ekstrak kulit jengkol (20\%-80\%) tidak berbeda nyata dengan perlakuan EJ0 kontrol negatif (-) tanpa perlakuan tetapi tidak berbeda nyata dengan perlakuan EJ1 kontrol positif (+) fungisida sintetis Benlox 50 WP 0,2\%. Pada pengamatan rata- rata persentase penghambatan pertumbuhan jamur pathogen Cercospora capsici menunjukkan perlakuan EJ6 sudah memberikan hasil yang dapat menghambat pertumbuhan koloni jamur (Colletotrichum capsici) di cawan petri, perlakuan ekstrak kulit jengkol (50\%), berbeda sangat nyata dengan EJ2 ekstrak kulit jengkol (10\%), dan berbeda sangat nyata terhadap perlakuan EJ3 dan EJ4 ekstrak kulit jengkol (20\% dan 30\%), akan tetapi pada perlakuan EJ6 sampai EJ11 pemberian ekstrak kulit jengkol tidak berbeda nyata dengan perlakuan EJ1 kontrol positif (+) fungisida sintetis Benlox 50 WP 0,2\%. Pada Perlakuan EJ6 ekstrak kulit jengkol (50\%) jamur patogen Cercospora capsici merupakan perlakuan yang sudah mampu megambat pertumbuhan koloni jamur karena setara dengan perlakuan EJ1 kontrol positif (+) fungisida sintetis Benlox $50 \mathrm{WP} 0,2 \%$.

Ekstrak kulit jengkol menunjukan ekstrak yang aktif dalam menghambat pertumbuhan mikroba (jamur). Hal ini sejalan dengan penelitian terdahulu dilaporkan bahwa senyawa aktif kulit jengkol yang memiliki aktivitas antimikroba dan bersifat bakteriosida pada konsentrasi $60 \%$ adalah senyawa bahan aktif tanin (Noerbaeti. E, dkk. 2016). Berdasarkan penelitian Noerbaeti. E, dkk. (2016) terdahulu dapat dilihat bahwa pengujian ekstrak kulit jengkol ternyata hasilnya lebih baik dalam menghambat pertumbuhan jamur patogen dibandingkan dengan bakteri. Pada jamur patogen Colletotrichum capsici konsentrasi 20\% sudah dapat menghambat pertumbuhan jamur sedangkan konsentrasi $90 \%$ dan 50\% dapat menghambat pertumbuhan jamur patogen Fusarium oxysporum dan Cercospora capsici.

\section{Morfologi Karakteristik Koloni}

Berdasarkan hasil identifikasi secara makroskopis di Laboratorium Proteksi Tanaman Fakultas Pertanian Universitas Medan Area, yang didasarkan pada karakteristik morfologi jamur pada hari ke-8 setelah diinkubasi pada medium PDA yaitu Colletotrichum capsici, Fusarium oxysporum dan Cercospora capsici sebagai dari hasil identifikasi secara makrokopis menunjukkan bahwa jamur Colletotricum capsici dalam media PDA tanpa perlakuan menunjukkan bahwa koloni biakan jamur menghasilkan banyak miselium, morfologi berbeda juga terlihat pada perlakuan ekstrak kulit jengkol (Pithecelobium jiringa) 10\% terlihat bahwapertumbuhan miselium koloni biakan murni jamur terlihat meluas dan tipis, koloni tidak berwarna atau transparan dan tidak adaperubahan warna pada permukaan koloni jamur pada kultur tua, hal ini dikarenakan pengaruh dari pemberian ekstrak kulit jengkol (Pithecelobium jiringa) pada media pertumbuhan jamur dengan konsentrasi $10 \%$.

Hasil identifikasi secara makrokopis menunjukkan bahwa jamur Fusarium oxysporum dalam media tanpa perlakuan dan ekstrak kulit jengkol 30\%, diatas penyebab penyakit tanaman cabai merah. Biakan jamur Colletotrichum Capsici yang telah berhasil diisolasi dan tidak terkontaminasi pada media PDA berwarna kelabu dengan miselium berwarna kelabu keputihan yang bertumbuh secara bertahap (Fitriani, 2014), menunjukkan bahwa mempunyai kenampakan morfologi yang sama yaitu koloni putih seperti kapas, bagian tepi tidak rata, dan miselium udara sedikit. Hal ini menunjukan 
bahwa ekstrak kulit jengkol konsentrasi $30 \%$ sama sekali tidak mempengaruhi karakteristik morfologi jamur Fusarium oxysporum. Hasil identifikasi secara makrokopis juga menunjukkan hasil yang sama dengan jamur Fusarium yaitu tidak terpengaruh dalam perubahan karakteristik morfologi. Jamur Cercospora capsici mempunyai kenampakan yang sama yaitu warna miselium putih pucat, arah pertumbuhan kesamping dan ke atas, struktur miselium agak kasar.Hal ini menunjukan bahwa ekstrak kulit jengkol (Pithecelobium jiringa) konsentrasi 30\% sama sekali tidak mempengaruhi karakteristik morfologi jamur Cercospora capsici.

\section{SIMPULAN}

Berdasarkan hasil uji skrining fitokimia yang dilakukan kulit jengkol mengandung senyawa kimia flavonoid, tannin, saponin, alkaloida, dan steroid/triterpenoid. Dan juga terlihat pada hasil pemberian ekstrak kulit jengkol (Pithecelobium jiringa) pada PDA dapat mengendalikan pertumbuhan cendawan patogen (Colletothricum capsici, Fusarium oxysporum dan Cercospora capsici) penyebab penyakit pada tanaman cabai merah (Capsicum annum L.) dan bersifat biofungisida setara dengan penggunaan fungisida sintetik 50 WP 0,2\%. Pemberian ekstrak kulit jengkol (Pithecelobium jiringa) konsentrasi $20 \%$ sangat nyata menekan pertumbuhan koloni Colletotrichum capsici pada perlakuan konsetrasi $90 \%$ sangat nyata menekan pertumbuhan koloni pada jamur Fusarium oxysporum dan pada konsentrasi 50\% sangat nyata menekan pertumbuhan koloni jamur Cercospora capsici. Pada jamur Fusarium oxysporum dalam media PDA tanpa perlakuan dan kulit jengkol (Pithecelobium jiringa) 30\%, diatas menunjukkan bahwa mempunyai kenampakan morfologi yang sama yaitu koloni putih seperti kapas, bagian tepi tidak rata, dan miselium udara sedikit. Hal ini menunjukan bahwa dari Gambar biakan jamur Cercospora capsici secara makroskopik cendawan ini menunjukan warna hifa hampir keputih keemasan. Hal ini menunjukan bahwa ekstrak kulit jengkol (Pithecelobium jiringa) konsentrasi 30\% sama sekali tidak mempengaruhi karakteristik morfologi jamur Cercospora capsici. Sebaiknya perlu dilakukan uji lapangan secara (in vivo) pada tanaman cabai merah dengan luasan areal yang lebih bervariasi dan juga perlu dilakukan nya uji skrining fitokimia yang lebih spesifik dan pengaruhnya terhadap berbagai penyakit patogen dari beberapa jenis tanaman yang berbeda.

\section{DAFTAR PUSTAKA}

Agnetha, A. Y., (2005), Efek ekstrak sebagai Larvasida Nyamuk Aedes sp. Skripsi, Universitas Brawijaya Malang, Indonesia.

Ambarningrum, T.B., Arthadi, P. Hery, dan P. Slamet. (2007). Ekstrak Kulit Jengkol (Pithecellobium lobatum): PengaruhnyaSebagai Anti Makan Dan Terhadap Efisiensi Pemanfaatan MakananLarva Instar V Heliothis armigera. J. Sains MIPA13:165-170

Aminah. (2001). S. rarak, D. metel dan E. prostata sebagai Larvasida Aedes aegypti, Cermin Dunia Kedokteran No. 131.

Djunaedy, A. (2008). Aplikasi Fungisida Sistemik dan Pemanfaatan Mikoriza dalam Rangka Pengendalian Patogen Tular Tanah pada Tanaman Kedelai (Glycine max L.). Embryo, 5 (2): 149-157.

Efri. (2010). Pengaruh Ekstrak Berbagai Bagian Tanaman Mengkudu (Morinda citrifolia) Terhadap Perkembangan Penyakit Antraknosa Pada Tanaman Cabe (Capsicum annuum L.). Lampung. Jurusan Proteksi Tanaman, Fakultas Pertanian, Universitas Lampung. J. HPT Tropika. ISSN 14117525. Vol. 10, No. 1: 52 - 58

Firdaus. (2008). Varitas Cabe Tahan Penyakit Tanpa Obat \& Pestisida. http://www.kilasberita.com/ kb-news/kilas-dunia. Diakses 3 Februari 2018, 20.00 WIB.

Melly, F. (2014). Mikobiota Pada Buah Cabai: Pengaruhnya Terhadap Colletotrichum capsici, Cendawan Penyeba Antraknosa. Departemen Biologi Fakultas Matematika Dan Ilmu Pengetahuan Alam Institut Pertanian Bogor. 
Siswandi, Retna Astuti Kuswardani, \& Maimunah, Uji In-Vitro Ekstrak Kulit Jengkol (Pithecullum jiringa)

Gholib, D. (2009). Uji Daya Hambat Daun Senggani (Melastoma malabathricum L.) terhadap Trichophyton mentagrophytees dan Candida albicans. Berita Biologi. Balai Besar Penelitian Veteriner Bogor. 9(5).253-259.

Hutasuhut, A.B., (2012), Banjir, Jengkol, Rahudman, http://www.hariansumutp os.com/2012/01/23377/ba njir-jengkol- rahudman.html, 13 Maret 2012.

Kalaisezhiyen P, Sasikumar V. (2012). GC-MS evaluation of chemical constituents from methanolic leaf extract of Kedrostis foetidissima (Jacq.) Cogn. Asian Journal of Pharmaceutical and Clinical Research. Vol 5(4): 77-81.

Kardinan, A. (2001). Pestisida nabati, ramuan, dan aplikasi. PT Penebar Swadaya, Jakarta.

Mustanir, Hendra, F., Nurhaida, dan Nurdin, S. (2013). Antifungal Ekstrak N-Heksana Tumbuhan Obat di Aceh terhadap Candida albicans. J. Ind. Soc. Integ. Chem, 5 (2): 7-14.

Nurussakinah. (2010). Skrinning Fitokimia dan Uji Aktivitas Antibakteri Ekstrak Kulit Buah Tanaman Jengkol (Pithecellobium jiringa (Jack) Prain) Terhadap Bakteri Streptococcus mutans, Staphylococcus aureus, dan Eschericia coli, Skripsi, Fakultas Farmasi, USU, Medan. 45

Olivia, F., Alam, S., dan Hadibroto, I. (2004). Seluk Beluk Food Suplemen. Jakarta: Gramedia.

Osbourn AE. (1996). Preformed antimicrobial compounds and plant defense againts fungal attack. Plant Cell.8: 1821-1831.

Patimah, S., Abun, and Supratman. R.H. (2012). Pengaruh Penambahan Ekstrak Kulit Jengkol (Pithecellobiumjiringa (Jack) Prain) dalam Ransum Terhadap Jumlah koloni Bakteri Escherichia coli dan Lactobacillus sp. Pada usus Halus Ayam Broiler. Thesis Fakultas Peternakan Universitas Padjadjaran.

Phillips, D \& Hossein, G (2008), 'Strawberry root and crown rot disease survey 2005 and 2006 seasons'. Departement of Agriculture and Food Government of Western Australia. Bulletin 4747, pp. 72 - 83.

Pradani F. Y. (2009). Indeks Pertumbuhan Larva Aedes aegypti L. Yang Terdedah Dalam Ekstrak Air Kulit Jengkol (Pithecellobium lobatum). Aspirator. 1 (2): 81-86.

Siswandi. Ahmad, F. Ahmad, A. Ahmad, R. (2016). Laporan Program Kreativitas Mahasiswa (PKMP). Judul Program Uji Ekstrak Kulit Jengkol (Pithecellobium Jiringa) sebagai Biofungisida Terhadap Penyakit Antraknosa (Colletotrichum Capsici) Pada Tanaman Cabai (Capsicum Annum L). Universitas Medan Area Medan 2016.

Sugianitri, N. K. (2011). Ekstrak Biji Buah Pinang (Areca catechu L.) dapat Menghambat Pertumbuhan Koloni Candida albicans secara In Vitro pada Resin Akrilik Heat Cured. Tesis. Program Pascasarjana Program Studi Ilmu Biomedik Universitas Udayana, Bali.

Thomas M. Little and F. Jackson Hils, (1978). Agricultural Experimentation. United State Of America Canada. Watson RR, Preedy VR. (2007). Botanical Medicine in Clinical Practice. Cambridge (UK): Cromwell Press.

Wulandari, (2012). Aktivitas Antijamur Senyawa Bioaktif Ekstrak Gelidium latifolium terhadap Candida albicans. Jurnal Pengolahan dan Bioteknologi Hasil Perikanan. 2012; 1 (1): 1-8. Diakses 26 Juli 2018.

Candra, I. aulia, Oktavioni, M., Marlinda, Y., Nova, B., Suliansyah, I., Handayani, T., Author, C., \& Jamsari, J. (2019). In Vitro Interaction between Geminivirus Replicase Protein and the Npr1 Gene Promoter from Chilli Pepper (Capsicum annuum). In International Journal of Agriculture and Biological Sciences-ISSN. http://milou.science.uu.nl/services/3DD-ART/

Hasibuan, S., Pranata, Y., \& Ifan Aulia Candra, D. (2020). Potential Antifungal Compound from Gliricidia Maculate Leaf Extract against Phatogenic Fungi (Colletothricum Capsici, Fusarium Oxysporum And Cercospora Capsici) on Chili Pepper Author's Details. In International Journal of Agriculture and Biological Sciences-ISSN.

Adetiya, N., Hutapea, S., \& Suswati, S. (2017). Pertumbuhan Dan Produksi Tanaman Cabai Merah (Capsicum annum L.) Bermikoriza Dengan Aplikasi Biochar Dan Pupuk Kimia. Agrotekma: Jurnal Agroteknologi dan Ilmu Pertanian, 1(2), 126-143. doi:https://doi.org/10.31289/agr.v1i2.1130

Babara Dalimunthe, M., Azwan, A., \& L. Panggabean, E. (2017). Pertumbuhan Dan Produksi Tanaman Cabai (Capsicum annum L.) Terhadap Pemberian Pupuk Organik Pada Berbagai Media Tanam. Agrotekma: Jurnal Agroteknologi dan Ilmu Pertanian, 1(1), 1-11. doi:https://doi.org/10.31289/agr.v1i1.1097

Eliyatiningsih, E., \& Mayasari, F. (2019). EFISIENSI PENGGUNAAN FAKTOR PRODUKSI PADA USAHATANI CABAI MERAH DI KECAMATAN WULUHAN KABUPATEN JEMBER. JURNAL AGRICA, 12(1), 7-16. doi:https://doi.org/10.31289/agrica.v12i1.2192

Hutauruk, D. (2018). POTENSI BAKTERI KITINOLITIK NR09 PADA BEBERAPA MEDIA PEMBAWA DALAM MENGHAMBAT PERTUMBUHAN JAMUR PATOGEN Sclerotium rolfsii dan Fusarium oxysporum PADA BENIH CABAI MERAH (Capsicum annuum L.). BIOLINK: Jurnal Biologi Lingkungan Industri Kesehatan, 4(2), 138-151. doi:https://doi.org/10.31289/biolink.v4i2.1182

Ilyasa, M., Hutapea, S., \& Rahman, A. (2018). Respon Pertumbuhan dan Produksi Tanaman Cabai Rawit (Capsicum frutescens L) terhadap Pemberian Kompos dan Biochar dari Limbah Ampas Tebu. 
Jurnal Ilmiah Pertanian (JIPERTA), 2(2) 2020: 144-157,

Agrotekma: Jurnal Agroteknologi dan Ilmu Pertanian, 3(1), 39-49. doi:https://doi.org/10.31289/agr.v3i1.1119

Sihotang, S., Renfiyeni, R., Suliansyah, I., \& Jamsari, J. (2019). Induksi Kalus dengan BAP (Benzylaminopurin) dan IAA (Indoleacetic acid) pada Tanaman Cabai (Capsicum annuum L.) Lokal Genotipe Lotanbar Sumatera Barat. Agrotekma: Jurnal Agroteknologi dan Ilmu Pertanian, 3(2), 67-74. doi:https://doi.org/10.31289/agr.v3i2.2547

Syahputra, E., Astuti K, R., \& Indrawaty, A. (2017). Kajian Agronomis Tanaman Cabai Merah (Capsicum annum L.) Pada Berbagai Jenis Bahan Kompos. Agrotekma: Jurnal Agroteknologi dan Ilmu Pertanian, 1(2), 92-101. doi:https://doi.org/10.31289/agr.v1i2.1127 